\title{
Timing of Preharvest Infection of Pear Fruit by Botrytis cinerea and the Relationship to Postharvest Decay
}

C. L. Lennox, ARC-Plant Protection Research Institute, Weeds Pathology Unit, Private Bag X5017, Stellenbosch 7599, South Africa, and R. A. Spotts, Oregon State University Mid-Columbia Agricultural Research and Extension Center, 3005 Experiment Station Drive, Hood River 97031

\begin{abstract}
Lennox, C. L., and Spotts, R. A. 2004. Timing of preharvest infection of pear fruit by Botrytis cinerea and the relationship to postharvest decay. Plant Dis. 88:468-473.

Botrytis cinerea causes significant levels of postharvest decay in the winter pear cultivar d'Anjou. The objectives of this study were to determine the timing of B. cinerea infection of pear stems and calyxes in the orchard during the growing season, to investigate the development of gray mold in storage, and to determine whether preharvest levels of $B$. cinerea in pear stems and calyxes can be used as predictors of gray mold levels observed in storage. Very low levels of B. cinerea were isolated from stem tissue prior to harvest. In a single year repeat experiment, stems sampled at harvest had higher levels of infection than those sampled earlier in the season. Little or no stem end gray mold was detected in fruit after 3 months in air-storage; however, incidence increased between 6 and 8 months. Calyx end gray mold was detected at low levels in fruit stored for up to 8 months. The mean incidence of stem end gray mold was 3.6 and $2.0 \%$, and incidence of calyx end gray mold was 1.2 and $0.2 \%$, in 1996 and 1997, respectively. Calyxes were susceptible to infection soon after full bloom; however, inoculation of calyxes in April or May did not result in higher levels of calyx end gray mold in storage. Therefore, preharvest level of calyx infection is a poor predictor of calyx end gray mold in storage. In addition, application of benomyl in the orchard reduced the level of B. cinerea in blossoms but had no effect on levels of calyx end gray mold of fruit in storage. Packing and shipping fruit within 3 to 6 months of harvest may mitigate economic losses due to gray mold.
\end{abstract}

Most winter pears for fresh consumption in the United States are grown and shipped from packinghouses in Oregon and Washington (10). Postharvest decay causes serious economic losses for packinghouses as a result of loss of fruit sold, as well as costs incurred from repacking. Growers are penalized financially by the packinghouse if their fruit exceeds a $2 \%$ decay level. Surveys of culled pear fruit from packinghouses in the Mid-Columbia region of Oregon and Washington $(12,13)$ showed that Botrytis cinerea Pers.:Fr. is a major pathogen involved in postharvest decay of the pear (Pyrus communis L.) cultivar d'Anjou in the region, and that stem-end infections caused significantly higher levels of decay than calyx-end infections.

The short, fleshy stems of 'd'Anjou' pear fruit appear to be highly susceptible to infection and decay by $B$. cinerea. It is not known whether infections prior to harvest are correlated with the levels of stem end gray mold observed in stored

Corresponding author: C. L. Lennox

E-mail: vredcl@plant3.agric.za

Accepted for publication 28 November 2003.

Publication no. D-2004-0217-02R

(C) 2004 The American Phytopathological Society
'd'Anjou' fruit. Because stem end decay caused by $B$. cinerea is a major component of postharvest decay $(12,13)$, determining when stem end infections occur has become a research priority.

It is widely assumed that infections resulting in calyx end gray mold occur at or around full bloom. Previous results (12) from isolation of $B$. cinerea from calyx components of blossoms and fruit from trees not sprayed with fungicides in both Hood River, OR, and Somerset West, South Africa, indicated that calyx infections occurred at two distinct peaks, the main one about a month after full bloom and another much smaller peak just prior to harvest. It was concluded that the application of an effective fungicide to the blossoms soon after full bloom would protect them from infection in the orchard and should significantly reduce the level of calyx end gray mold in storage. Furthermore, we also suggested that a postharvest decay prediction program would significantly reduce losses due to decay.

The objectives of this study were to determine the timing of $B$. cinerea infection of pear stems and calyxes in the orchard during the growing season, to investigate the development of gray mold in storage, and to determine whether preharvest levels of $B$. cinerea in pear stems and calyxes can be used as predictors of gray mold levels observed in storage.
MATERIALS AND METHODS

The winter pear cultivar d'Anjou was used throughout this study.

Timing of infection of pear fruit stems. Colonization of pear fruit stem tissue by $B$. cinerea was determined in 14 commercial pear orchards at monthly intervals from April to August in 1996 and 1997, and in five and six orchards at commercial harvest (September) in 1997 and 1998, respectively. Clusters of blossoms or immature fruit were picked from five arbitrarily selected trees. In the laboratory, 20 individual blossoms or immature fruit were detached at the prospective abscission zone. Twenty mature fruit were detached at the abscission zone from the parent tree. For the 1998 harvest sampling time, 100 mature fruit were picked. The blossoms or fruit were surface disinfested in $70 \%$ ethanol for $30 \mathrm{~s}$, then $120 \mathrm{~s}$ in $0.05 \%$ sodium hypochlorite, followed by $30 \mathrm{~s}$ in $70 \%$ ethanol. Blossoms and fruit were air-dried in a laminar airflow cabinet. Once dry, the stems were dissected from the blossoms or fruit, leaving a small amount of pear fruit material attached to each stem. The stems were cut in half lengthwise, and each half cut into three pieces before being transferred onto petri dishes containing Kerssies medium, an agar medium semiselective for $B$. cinerea (9). Stem sections were incubated at approximately $22^{\circ} \mathrm{C}$ and examined weekly for 4 weeks for growth of $B$. cinerea.

The experimental design was a randomized block design with six treatments (monthly intervals after full bloom, April through August, and at harvest) and 14 block replications (orchards). This was repeated for two seasons $(1996,1997)$. The experimental units were 20 blossoms or fruit for sampling times in 1996 and 1997, and 100 fruit for 1998. The response variable was percent incidence of Botrytis infection in the stems. An analysis of variance was performed separately for each year, and Fisher's least significant difference was calculated at the $5 \%$ significance level to compare treatment means.

Monitoring of stem end and calyx end gray mold of fruit in storage. Ten boxes of mature fruit (18 kg of fruit per box) from 14 commercial orchards in the MidColumbia region were harvested in 1996 and 1997 and placed in air storage at $-0.5^{\circ} \mathrm{C}$. Fruit were evaluated for symptoms of stem end and calyx end gray mold after 
3,6 , and 8 months, and 8 months followed by a ripening period of 1 week at $20^{\circ} \mathrm{C}$. The incidence of stem end and calyx end gray mold occurring in fruit at 3,6, and 8 months in storage, and 8 months plus 1 week ripening period at $20^{\circ} \mathrm{C}$ was recorded.

The experimental design was a randomized block design with four treatments $(3$, 6 , and 8 months in storage, and 8 months followed by 1 week of ripening at $20^{\circ} \mathrm{C}$ ) and 14 block replications (orchards). The experimental units were 10 boxes of fruit. The response variable was percent stem end and calyx end gray mold recorded in storage per experimental unit. This experiment was repeated for two seasons (1996, 1997). An analysis of variance was performed separately for each year, and Fisher's least significant difference was calculated at the 5\% significance level to compare treatment means.

Timing of infection of pear fruit calyxes. Timing of preharvest infection of pear calyxes was investigated by monthly inoculations of fruit in one orchard from April to August in 1996 and 1997. Calyxes of blossoms or fruit of three pear trees were inoculated each month by atomizing either a wet inoculum preparation of $1 \times$ $10^{6} \mathrm{~B}$. cinerea conidia per $\mathrm{ml}$ of sterile distilled water, or a dry inoculum preparation of $0.2 \mathrm{~g}$ of $B$. cinerea conidia per $20 \mathrm{~g}$ of talc into each calyx. Conidia were harvested from 14-day-old cultures grown on potato dextrose agar acidified with $1.5 \mathrm{ml}$ of lactic acid per liter. Nontreated blossoms and fruit served as controls.

B. cinerea infection of calyxes in inoculated blossoms and fruit. Twenty blossoms or fruit from each inoculation time were sampled 1 month after inoculation. For isolation of $B$. cinerea, blossoms or fruit were dipped briefly in $70 \%$ ethanol, then in $0.05 \%$ sodium hypochlorite before drying in a laminar airflow cabinet. Stamens were removed with a sterile fine-tip forceps and placed onto Kerssies medium (9). All 20 stamens per blossom were placed in one petri dish. This procedure was repeated for all pistils and sepals from each calyx, which were then placed onto a second petri dish containing Kerssies medium. Calyx parts were incubated at approximately $22^{\circ} \mathrm{C}$ and examined weekly for 4 weeks for growth of $B$. cinerea. The mean incidence (\%) of $B$. cinerea-infected calyxes in nontreated, wet inoculum, and dry inoculum treated blossoms and fruit, and the incidence of infected calyxes after each inoculation time (April through $\mathrm{Au}-$ gust) were recorded.

The experimental design was a completely randomized design with three replications repeated twice $(1996,1997)$. The treatment design was a $5 \times 3$ factorial. The factors were 5 inoculation times (April through August) and 3 inoculation treatments (control, wet, dry). The experimental units were 20 blossoms or fruit. The response variable was percent incidence of Botrytis infection in the calyxes of the blossoms or fruit. Incidence was recorded as binomial type data and was transformed to percentages and logits before being subjected to analysis of variance. Fisher's least significant difference was calculated at the $5 \%$ significance level to compare treatment means.

Calyx end gray mold in inoculated fruit. At commercial harvest, three boxes of inoculated fruit (18 kg fruit, or approximately 100 fruit per box) per inoculum treatment (control, wet, and dry) and time (April through August) were picked and placed in air storage at $-0.5^{\circ} \mathrm{C}$. All fruit were evaluated for calyx end gray mold after 8 months in storage followed by a ripening period of 1 week at $20^{\circ} \mathrm{C}$.

The experimental design was a randomized block design with three replications repeated twice $(1996,1997)$. The treatment design was a $5 \times 3$ factorial. The factors were 5 inoculation times (April through August) and 3 inoculation treatments (control, wet, dry). The experimental units were three boxes of fruit. The response variable was percent calyx end gray mold incidence recorded in storage per experimental unit. Incidence was recorded as binomial type data and was transformed to percentages and logits before being subjected to analysis of variance. Fisher's least significant difference was calculated at the $5 \%$ significance level to compare treatment means.

Effect of benomyl spray schedules on calyx end gray mold. Three commercial pear orchards located in the Mid-Columbia region of Oregon and Washington were selected. In each orchard, 33 trees were randomly assigned to 11 groups of 3 trees each. One group of three trees (control) was left unsprayed throughout the experiment. Starting at full bloom in 1996 and 1997, benomyl (Benlate 50WP, Dupont de Nemours, Inc., Wilmington, DE) was applied at a rate of $1.2 \mathrm{~g} /$ liter and 1,893 liters/ha to the 10 remaining groups. Every 2 weeks, a different group was left untreated and all others treated with fungicide. This 2-week schedule was maintained for 20 weeks (10 fungicide applications).

B. cinerea infection of calyxes in blossoms and fruit subjected to a preharvest benomyl spray schedule. Twenty replicate blossom and fruit samples were taken from each of the three trees in each orchard that had not been sprayed 2 weeks prior to the sample date, and from trees that had not been sprayed throughout the entire season. $B$. cinerea was isolated from the calyxes of blossoms and fruit using the method described above. Incidence of $B$. cinerea infection of calyxes was recorded.

The experimental design was a completely randomized design with three replications repeated twice $(1996,1997)$. The treatment design was an $11 \times 2$ factorial. The factors were 11 spray schedules and 2 spray treatments (control, sprayed). The experimental units were 20 blossoms or fruit. The response variable was percent incidence of Botrytis infection in the calyxes of the blossoms or fruit. An analysis of variance was performed separately for each year, and Fisher's least significant difference was calculated at the $5 \%$ significance level to compare treatment means.

Calyx end gray mold in fruit subjected to a preharvest benomyl spray schedule. At harvest, three boxes of fruit $(18 \mathrm{~kg}$ of fruit per box) were picked from trees receiving each of the different fungicide schedules in each of the three orchards and placed in air storage at $-0.5^{\circ} \mathrm{C}$. Fruit were evaluated for calyx end gray mold after 8 months in storage followed by a ripening period of 1 week at $20^{\circ} \mathrm{C}$.

The experimental design was a randomized block design with 11 treatments (2weekly benomyl spray schedules) and 3 block replications (orchards). The experimental units were three boxes of fruit. The response variable was percent calyx end gray mold recorded in storage per experimental unit. This experiment was repeated for two seasons $(1996,1997)$. An analysis of variance was performed separately for each year, and Fisher's least significant difference was calculated at the $5 \%$ sig-

Table 1. Isolation of Botrytis cinerea from 'd'Anjou' pear stems during the 1996 and 1997 growing seasons and harvest in 1997 and 1998

\begin{tabular}{|c|c|c|c|c|c|c|}
\hline \multirow[b]{2}{*}{ Month } & \multicolumn{2}{|c|}{$1996^{x}$} & \multicolumn{2}{|c|}{$1997^{x, y}$} & \multicolumn{2}{|c|}{$1998^{y}$} \\
\hline & $\begin{array}{c}\text { Infected } \\
\text { stems (\%) }\end{array}$ & $\begin{array}{c}\text { Orchards } \\
(\%)\end{array}$ & $\begin{array}{c}\text { Infected } \\
\text { stems (\%) }\end{array}$ & $\begin{array}{c}\text { Orchards } \\
(\%)\end{array}$ & $\begin{array}{c}\text { Infected } \\
\text { stems (\%) }\end{array}$ & $\begin{array}{c}\text { Orchards } \\
(\%)\end{array}$ \\
\hline April & $0.0 \pm 0.0 \mathrm{a}^{\mathrm{z}}$ & 0 & & & $\ldots$ & .. \\
\hline May & $0.0 \pm 0.0 \mathrm{a}$ & 0 & $0.2 \pm 0.2 \mathrm{~b}$ & 5 & $\ldots$ & $\ldots$ \\
\hline June & $0.0 \pm 0.0 \mathrm{a}$ & 0 & $0.0 \pm 0.0 \mathrm{~b}$ & 0 & $\ldots$ & $\ldots$ \\
\hline July & $1.1 \pm 1.1 \mathrm{a}$ & 5 & $0.4 \pm 0.3 b$ & 10 & $\ldots$ & $\ldots$ \\
\hline August & $1.4 \pm 0.6 \mathrm{a}$ & 20 & $2.1 \pm 1.6 \mathrm{~b}$ & 15 & $\ldots$ & $\ldots$ \\
\hline Harvest & $\ldots$ & $\ldots$ & $6.6 \pm 2.4 \mathrm{a}$ & 100 & $0.6 \pm 0.3$ & 50 \\
\hline
\end{tabular}

${ }_{x}$ April through August values are the mean \pm standard error and are based on isolation from 20 stems per orchard from 14 orchards.

${ }^{y}$ Harvest values are the mean \pm standard error and are based on 20 stems per orchard from five orchards (1997) and 100 stems per orchard from six orchards (1998).

${ }^{\mathrm{z}}$ Numbers followed by the same letter within columns are not significantly different at $P=0.05$ according to Fisher's least significant difference. 
nificance level to compare treatment means.

\section{RESULTS}

Timing of infection of pear fruit stems. The data for each year were analyzed separately due to heterogeneity of the variances. The percentage of stems infected by $B$. cinerea did not differ for stems sampled from April to August in 1996 and 1997 (Table 1). In all cases, $B$. cinerea was isolated from the abscission zone of the stem. Levels of infection were higher in stems sampled at harvest in September 1997 than at previous sample times, and the pathogen was isolated from 6.6 and $0.6 \%$ of stems at harvest in 1997 and 1998, respectively (Table 1). B. cinerea was isolated from stems in 20 and $15 \%$ of orchards in August 1996 and 1997, respectively, and 100 and $50 \%$ of orchards at harvest in September 1997 and 1998, respectively (Table 1).

Monitoring of stem end and calyx end gray mold of fruit in storage. The decay data for each year were analyzed separately due to heterogeneity of the variances. No stem end gray mold was detected in pears from any of the 14 commercial orchards sampled in 1996 and 1997 after 3 months in storage (Table 2). In 1996, the incidence of stem end gray mold increased between 3 and 6 months, and 6 and 8 months in storage. The mean percent stem end gray mold in fruit after 8 months in storage and a 1-week ripening period was 3.6 and $2.0 \%$ in 1996 and 1997, respectively (Table 2). The 1-week ripening period at $20^{\circ} \mathrm{C}$ did not significantly increase the incidence of stem end gray mold in either 1996 or 1997.

Calyx end gray mold was detected at low levels in fruit stored for 3 months in 1996 but not in 1997 (Table 2). After 8 months in storage, mean incidence of calyx end gray mold had increased in fruit from the 1996 crop. After 8 months air storage plus 1 week ripening at $20^{\circ} \mathrm{C}$, the mean incidence of calyx end gray mold was 1.2 and $0.2 \%$ for the 1996 and 1997 crops, respectively (Table 2).

Timing of infection of pear fruit calyxes. Due to homogeneity of variances in the data of $B$. cinerea infection of calyxes in inoculated blossoms and fruit, as well in the data of calyx end gray mold in inoculated fruit, an analysis of data for the 2 years (1996 and 1997) combined was carried out for each of these data sets. There was no evidence against normality in the logit transformed data of $B$. cinerea infection of calyxes in inoculated blossoms and fruit $(P=0.1102)$, or in the data of calyx end gray mold in inoculated fruit $(P=$

Table 2. Incidence of stem end and calyx end gray mold in 1996 and 1997 'd'Anjou' pear fruit crop during air storage and after ripening

\begin{tabular}{lllccc}
\hline & \multicolumn{4}{c}{ Gray mold incidence (\%) } \\
\cline { 2 - 3 } $\begin{array}{l}\text { Storage period } \\
\text { (months) }\end{array}$ & \multicolumn{2}{c}{ Stem end } & & \multicolumn{2}{c}{ Calyx end } \\
\cline { 2 - 3 } \cline { 5 - 6 } & $\mathbf{1 9 9 6}$ & $\mathbf{1 9 9 7}$ & & $\mathbf{1 9 9 6}$ & $\mathbf{1 9 9 7}$ \\
6 & $0.0 \mathrm{a}$ & $0.0 \mathrm{a}$ & & $0.1 \mathrm{a}$ & $0.0 \mathrm{a}$ \\
8 & $1.7 \mathrm{~b}$ & $0.5 \mathrm{a}$ & & $0.4 \mathrm{ab}$ & $0.0 \mathrm{a}$ \\
$8+$ ripening $^{2}$ & $3.4 \mathrm{c}$ & $1.7 \mathrm{~b}$ & & $0.8 \mathrm{bc}$ & $0.1 \mathrm{a}$ \\
\hline
\end{tabular}

${ }^{\mathrm{y}}$ Incidence based on 10 boxes of fruit per orchard from 14 orchards, about 100 fruit per box. Numbers followed by the same letter within columns are not significantly different at $P=0.05$ according to Fisher's least significant difference.

${ }^{\mathrm{z}}$ Fruit ripened for 1 week at $20^{\circ} \mathrm{C}$.
0.5199); therefore the data analysis was considered valid. Due to the high significance $(P=0.001)$ of the third order interaction effect $($ year $\times$ month $\times$ inoculum treatment), the lesser order interaction and main effect means were not examined. The back-transformed (year $\times$ month $\times$ inoculum treatment) mean percent incidences are presented in Table 3.

Results from 1996 isolations of $B$. cinerea from calyxes of blossoms and fruit do not indicate a specific period of increased susceptibility to infection by $B$. cinerea (Table 3). In fruit inoculated in 1996, levels of calyx end decay after 8 months plus 1 -week ripening period at $20^{\circ} \mathrm{C}$ were not significantly different from that in the noninoculated control fruit (Table 3). Significantly higher levels of $B$. cinerea were isolated from calyxes of wet-inoculated blossoms and fruit in April and May 1997 than in later months of that year, and higher incidences of calyx infection occurred in wet-inoculated than in nontreated blossoms and fruit in these 2 months (Table 3). Inoculations with dry conidia resulted in a higher incidence of calyx infection in April through June than in later months, and higher incidences of calyx infection occurred in dry-inoculated than in nontreated blossoms and fruit in April through June 1997 (Table 3). The incidence of calyx end gray mold was significantly higher in fruit wet-inoculated in May through August 1997 than in fruit wet-inoculated in April 1997, and was also higher than that in nontreated fruit (Table 3 ). Fruit inoculated with dry inoculum in June and August 1997 had significantly higher levels of calyx end gray mold than those inoculated in April, May, and July 1997. Fruit inoculated with dry inoculum in June and August 1997 had significantly higher levels of calyx end gray mold than nontreated control fruit (Table 3).

Effect of benomyl spray schedules on calyx end gray mold. The data for each year were analyzed separately due to het-

Table 3. Isolation of Botrytis cinerea from calyxes of inoculated 'd'Anjou' pear 1 month after inoculation, and incidence of calyx end gray mold in inoculated fruit after storage

\begin{tabular}{|c|c|c|c|c|c|c|c|}
\hline \multirow[b]{2}{*}{ Year } & \multirow{2}{*}{$\begin{array}{l}\text { Inoculation } \\
\text { month }\end{array}$} & \multicolumn{3}{|c|}{$\%$ Infected calyxes $^{u}$} & \multicolumn{3}{|c|}{$\%$ Calyx end gray mold after storage $^{v}$} \\
\hline & & Control $^{w}$ & Wet $^{x}$ & Dry $^{y}$ & Control $^{w}$ & Wet $^{x}$ & Dry $^{y}$ \\
\hline \multirow[t]{5}{*}{1996} & April & $10.0 \mathrm{efg}^{\mathrm{z}}$ & $3.3 \mathrm{~g}$ & $40.0 \mathrm{c}$ & $0.6 \mathrm{gh}$ & $0.0 \mathrm{~h}$ & $0.6 \mathrm{gh}$ \\
\hline & May & $10.0 \mathrm{efg}$ & $40.0 \mathrm{c}$ & $6.7 \mathrm{fg}$ & $0.6 \mathrm{gh}$ & $0.6 \mathrm{gh}$ & $0.6 \mathrm{gh}$ \\
\hline & June & $35.0 \mathrm{~cd}$ & $46.7 \mathrm{bc}$ & $46.7 \mathrm{bc}$ & $1.3 \mathrm{gh}$ & $0.6 \mathrm{gh}$ & $2.2 \mathrm{fgh}$ \\
\hline & July & $0.0 \mathrm{~g}$ & $26.7 \mathrm{cdef}$ & $6.7 \mathrm{fg}$ & $0.7 \mathrm{gh}$ & $3.0 \mathrm{fgh}$ & $1.5 \mathrm{gh}$ \\
\hline & August & $15.0 \mathrm{defg}$ & 30.0 cde & 26.7 cdef & $0.6 \mathrm{gh}$ & $4.2 \mathrm{fg}$ & $0.6 \mathrm{gh}$ \\
\hline \multirow[t]{5}{*}{1997} & April & $6.7 \mathrm{fg}$ & $40.0 \mathrm{c}$ & $46.7 \mathrm{bc}$ & $1.5 \mathrm{gh}$ & $2.0 \mathrm{fgh}$ & $0.8 \mathrm{gh}$ \\
\hline & May & $13.3 \mathrm{efg}$ & $66.7 \mathrm{~b}$ & $90.0 \mathrm{a}$ & $3.7 \mathrm{fgh}$ & $9.1 \mathrm{de}$ & $2.9 \mathrm{fgh}$ \\
\hline & June & $3.3 \mathrm{~g}$ & $6.7 \mathrm{fg}$ & 30.0 cde & $2.3 \mathrm{fgh}$ & $17.2 \mathrm{ab}$ & $12.3 \mathrm{~cd}$ \\
\hline & July & $0.0 \mathrm{~g}$ & $0.0 \mathrm{~g}$ & $0.0 \mathrm{~g}$ & $1.9 \mathrm{fgh}$ & $13.5 \mathrm{bc}$ & 5.7 ef \\
\hline & August & $0.0 \mathrm{~g}$ & $0.0 \mathrm{~g}$ & $0.0 \mathrm{~g}$ & $1.5 \mathrm{gh}$ & $21.2 \mathrm{a}$ & $16.8 \mathrm{~b}$ \\
\hline
\end{tabular}

u Percent infected calyxes determined by isolation of $B$. cinerea 1 month after inoculation.

v Percent decay after 8 months at $-0.5^{\circ} \mathrm{C}$ plus 1 week at $20^{\circ} \mathrm{C}$.

${ }^{w}$ Nontreated control blossoms and fruit.

x Calyxes of blossoms and fruit inoculated with wet inoculum preparation of $1 \times 10^{6} \mathrm{conidia} / \mathrm{ml}$.

${ }^{\mathrm{y}}$ Calyxes of blossoms and fruit inoculated with dry inoculum preparation of $0.2 \mathrm{~g}$ of conidia per $20 \mathrm{~g}$ of talc.

${ }^{\mathrm{z}}$ Means of isolation and storage data followed by a different letter differ significantly at $P=0.05$ according to Fisher's least significant difference. Percent infected calyxes $\mathrm{LSD}_{0.05}=20.51$. Percent calyx end gray mold after storage $\mathrm{LSD}_{0.05}=4.04$. 
erogeneity of the variances. In the 1996 experiments designed to determine the timing of calyx infection, calyxes from unsprayed control blossoms and fruit from orchard $\mathrm{C}$ showed a higher level of $B$. cinerea during the second period (beginning 9 May) than those from later periods. Although calyx infection was high in the second period in orchard $\mathrm{A}$ and the first period in orchard $\mathrm{B}$, in unsprayed control trees, infection levels were not significantly higher than those of later periods for these two orchards. Orchard A showed a higher incidence of $B$. cinerea infection in calyxes unprotected during the second unsprayed period (beginning 9 May) than later periods (Table 4), whereas orchards B and $\mathrm{C}$ had higher incidences of infection in calyxes unprotected during the first unsprayed period (beginning 25 April) than later periods (Table 4). During the 1997 growing season, calyxes from unprotected control trees showed significantly higher levels of $B$. cinerea later in the growing season, with a rise in incidence occurring during the fourth period (beginning 2 June) (Table 5). No significant differences in calyx infection were detected in sprayed trees from orchards B and C. Calyx infection was significantly higher in sprayed trees from orchard A that were left unsprayed during the fourth period (beginning 2 June) compared with earlier periods (Table 5). Calyx end decay in storage did not differ significantly in fruit from each of the unsprayed periods, or from the unprotected control trees in all three orchards in 1996 (Table 4) and 1997 (Table 5).

\section{DISCUSSION}

$B$. cinerea is responsible for a major portion of postharvest decay detected in winter pears in the Pacific Northwest $(12,13)$. In our study, mean incidence of stem end gray mold in stored fruit was 3.2 and $2.0 \%$, and that of calyx end gray mold was 1.2 and $0.3 \%$ in 1996 and 1997, respectively.

Our results of isolation data (1996 and 1997) showed very low levels of stem infection by $B$. cinerea prior to harvest, indicating that stem tissue is generally resistant until late summer (August). Stem end infections were observed at harvest in early September of 1997 and 1998. In 1997, stems sampled at harvest had higher levels of infection than those from earlier sample times. This experiment needs to be repeated to confirm these results. Susceptibility of 'd'Anjou' pear fruit to infection by $B$. cinerea increased during the final month before harvest (17). Contamination of the abscission zone of the stem of har-

Table 4. Influence of an unprotected 2-week period on calyx infection by Botrytis cinerea in 'd'Anjou' pears sprayed with benomyl, and levels of calyx end gray mold in fruit from three commercial orchards (A,B,C) after storage in 1996

\begin{tabular}{|c|c|c|c|c|c|c|c|c|c|}
\hline \multirow{2}{*}{$\begin{array}{l}\text { Unprotected } \\
\text { period starting } \\
\text { date }\end{array}$} & \multicolumn{3}{|c|}{$\begin{array}{c}\text { \% B. cinerea infection in nonsprayed } \\
\text { control calyxes }\end{array}$} & \multicolumn{3}{|c|}{$\begin{array}{c}\text { \% B. cinerea infection in calyxes after a } \\
\text { 2-week no spray period }{ }^{w}\end{array}$} & \multicolumn{3}{|c|}{$\%$ Calyx end gray mold in storage ${ }^{x}$} \\
\hline & $\mathbf{A}$ & B & C & $\mathbf{A}$ & B & C & $\mathbf{A}$ & B & C \\
\hline $25 \mathrm{Apr}$ & $0.0 \mathrm{a}^{\mathrm{y}}$ & $20.0 \mathrm{a}$ & $25.0 \mathrm{~cd}$ & $0.0 \mathrm{a}$ & $35.0 \mathrm{c}$ & $20.0 \mathrm{~b}$ & $0.2 \mathrm{a}$ & $0.0 \mathrm{a}$ & $0.7 \mathrm{a}$ \\
\hline 9 May & $35.0 \mathrm{a}$ & $0.0 \mathrm{a}$ & $36.7 \mathrm{~d}^{*}$ & $15.0 \mathrm{~b}$ & $10.0 \mathrm{~b}$ & $0.0 \mathrm{a}$ & $0.0 \mathrm{a}$ & $0.7 \mathrm{a}$ & $0.6 \mathrm{a}$ \\
\hline 23 May & $10.0 \mathrm{a}$ & $0.0 \mathrm{a}$ & $0.0 \mathrm{a}$ & $3.3 \mathrm{a}$ & $0.0 \mathrm{a}$ & $0.0 \mathrm{a}$ & $0.2 \mathrm{a}$ & $0.3 \mathrm{a}$ & $0.0 \mathrm{a}$ \\
\hline 5 Jun & $3.3 \mathrm{a}$ & $10.0 \mathrm{a}$ & $0.0 \mathrm{a}$ & $0.0 \mathrm{a}$ & $0.0 \mathrm{a}$ & $0.0 \mathrm{a}$ & $0.0 \mathrm{a}$ & $0.3 \mathrm{a}$ & $0.2 \mathrm{a}$ \\
\hline 19 Jun & $6.7 \mathrm{a}$ & $6.7 \mathrm{a}$ & $10.0 \mathrm{bc}$ & $0.0 \mathrm{a}$ & $0.0 \mathrm{a}$ & $0.0 \mathrm{a}$ & $0.0 \mathrm{a}$ & $0.0 \mathrm{a}$ & $0.2 \mathrm{a}$ \\
\hline $2 \mathrm{Jul}$ & $3.3 \mathrm{a}$ & $6.7 \mathrm{a}$ & $6.7 \mathrm{ab}$ & $0.0 \mathrm{a}$ & $0.0 \mathrm{a}$ & $0.0 \mathrm{a}$ & $0.0 \mathrm{a}$ & $0.5 \mathrm{a}$ & $0.4 \mathrm{a}$ \\
\hline $19 \mathrm{Jul}$ & $3.3 \mathrm{a}$ & $26.7 \mathrm{a}$ & $0.0 \mathrm{a}$ & $0.0 \mathrm{a}$ & $0.0 \mathrm{a}$ & $0.0 \mathrm{a}$ & $0.0 \mathrm{a}$ & $0.0 \mathrm{a}$ & $0.0 \mathrm{a}$ \\
\hline $31 \mathrm{Jul}$ & $13.3 \mathrm{a}$ & $10.0 \mathrm{a}$ & $10.0 \mathrm{bc}$ & $0.0 \mathrm{a}$ & $0.0 \mathrm{a}$ & $3.3 \mathrm{a}$ & $0.4 \mathrm{a}$ & $0.0 \mathrm{a}$ & $0.4 \mathrm{a}$ \\
\hline 14 Aug & $16.7 \mathrm{a}$ & $6.7 \mathrm{a}$ & $10.0 \mathrm{bc}$ & $3.3 \mathrm{a}$ & $0.0 \mathrm{a}$ & $0.0 \mathrm{a}$ & $0.5 \mathrm{a}$ & $0.6 \mathrm{a}$ & $0.2 \mathrm{a}$ \\
\hline $28 \mathrm{Aug}$ & $13.3 \mathrm{a}$ & $10.0 \mathrm{a}$ & $6.7 \mathrm{ab}$ & $0.0 \mathrm{a}$ & $0.0 \mathrm{a}$ & $0.0 \mathrm{a}$ & $0.4 \mathrm{a}$ & $0.0 \mathrm{a}$ & $0.3 \mathrm{a}$ \\
\hline \multicolumn{4}{|c|}{ Nonsprayed control $^{\mathrm{Z}}$} & & & & $0.8 \mathrm{a}$ & $0.5 \mathrm{a}$ & $0.8 \mathrm{a}$ \\
\hline
\end{tabular}

${ }^{\mathrm{v}}$ Isolation of $B$. cinerea from calyxes of control trees which remained unsprayed throughout the growing season.

${ }^{\mathrm{w}}$ Isolation of $B$. cinerea from calyxes of test trees which received an application of benomyl every 2 weeks, but which remained unsprayed for a 2 -week period.

$\times$ Storage in air at $-0.5^{\circ} \mathrm{C}$ for 8 months, followed by a 1 -week ripening period at $20^{\circ} \mathrm{C}$.

y Means down columns followed by the same letter are not significantly different at $P=0.05$ according to Fisher's least significant difference. * Indicates that infection level in nonsprayed control calyxes is significantly different from infection levels in the calyxes sampled after the unsprayed 2-week period from the same orchard according to Fisher's least significant difference $(P=0.05)$.

z \% Calyx end gray mold in nonsprayed control fruit in storage.

Table 5. Influence of an unprotected 2-week period on calyx infection by Botrytis cinerea in 'd'Anjou' pears sprayed with benomyl, and levels of calyx end gray mold in fruit from three commercial orchards (A, B, C) after storage in 1997

\begin{tabular}{|c|c|c|c|c|c|c|c|c|c|}
\hline \multirow{2}{*}{$\begin{array}{l}\text { Unprotected } \\
\text { period starting } \\
\text { date }\end{array}$} & \multicolumn{3}{|c|}{$\begin{array}{c}\text { \% } B \text {. cinerea infection in nonsprayed } \\
\text { control calyxes }\end{array}$} & \multicolumn{3}{|c|}{$\begin{array}{c}\% \text { B. cinerea infection in calyxes after a } \\
2 \text {-week no spray period }{ }^{w}\end{array}$} & \multicolumn{3}{|c|}{$\%$ Calyx end gray mold in storage ${ }^{x}$} \\
\hline & A & B & $\mathbf{C}$ & $\mathbf{A}$ & $\mathbf{B}$ & $\mathbf{C}$ & $\mathbf{A}$ & $\mathbf{B}$ & $\mathbf{C}$ \\
\hline $24 \mathrm{Apr}$ & $0.0 \mathrm{a}^{\mathrm{y}}$ & $0.0 \mathrm{a}$ & $0.0 \mathrm{a}$ & $0.0 \mathrm{a}$ & $0.0 \mathrm{a}$ & $0.0 \mathrm{a}$ & $0.4 \mathrm{a}$ & $0.0 \mathrm{a}$ & $0.3 \mathrm{a}$ \\
\hline 5 May & $16.7 \mathrm{abc}$ & $13.3 \mathrm{abc}$ & $13.3 \mathrm{~b}$ & $3.3 \mathrm{a}$ & $3.3 \mathrm{a}$ & $3.3 \mathrm{a}$ & $0.0 \mathrm{a}$ & $0.0 \mathrm{a}$ & $0.0 \mathrm{a}$ \\
\hline 19 May & $0.0 \mathrm{a}$ & $3.3 \mathrm{ab}$ & $0.0 \mathrm{a}$ & $0.0 \mathrm{a}$ & $3.3 \mathrm{a}$ & $0.0 \mathrm{a}$ & $0.4 \mathrm{a}$ & $0.2 \mathrm{a}$ & $0.0 \mathrm{a}$ \\
\hline 2 Jun & $43.3 \mathrm{c}$ & $23.3 \mathrm{bc}^{*}$ & $23.3 b^{*}$ & $23.3 \mathrm{~b}$ & $0.0 \mathrm{a}$ & $0.0 \mathrm{a}$ & $0.2 \mathrm{a}$ & $0.3 \mathrm{a}$ & $0.0 \mathrm{a}$ \\
\hline 19 Jun & $16.7 \mathrm{bc}$ & $10.0 \mathrm{abc}$ & $13.3 \mathrm{~b}$ & $10.0 \mathrm{ab}$ & $0.0 \mathrm{a}$ & $0.0 \mathrm{a}$ & $0.0 \mathrm{a}$ & $0.3 \mathrm{a}$ & $0.8 \mathrm{a}$ \\
\hline $2 \mathrm{Jul}$ & $33.3 \mathrm{bc}$ & $36.7 \mathrm{bc}$ & $10.0 \mathrm{~b}$ & $6.7 \mathrm{ab}$ & $0.0 \mathrm{a}$ & $0.0 \mathrm{a}$ & $0.8 \mathrm{a}$ & $0.0 \mathrm{a}$ & $0.0 \mathrm{a}$ \\
\hline $16 \mathrm{Jul}$ & $13.3 \mathrm{abc}$ & $40.0 c^{*}$ & $16.7 b^{*}$ & $3.3 \mathrm{a}$ & $0.0 \mathrm{a}$ & $0.0 \mathrm{a}$ & $0.2 \mathrm{a}$ & $0.4 \mathrm{a}$ & $0.3 \mathrm{a}$ \\
\hline $28 \mathrm{Jul}$ & $10.0 \mathrm{ab}$ & $33.3 c^{*}$ & $23.3 b^{*}$ & $3.3 \mathrm{a}$ & $0.0 \mathrm{a}$ & $0.0 \mathrm{a}$ & $0.3 \mathrm{a}$ & $0.4 \mathrm{a}$ & $0.7 \mathrm{a}$ \\
\hline $12 \mathrm{Aug}$ & $23.3 \mathrm{bc}$ & $33.3 \mathrm{c} *$ & $20.0 b^{*}$ & $6.7 \mathrm{ab}$ & $3.3 \mathrm{a}$ & $0.0 \mathrm{a}$ & $0.2 \mathrm{a}$ & $0.0 \mathrm{a}$ & $0.2 \mathrm{a}$ \\
\hline Nonsprayed control $^{\mathrm{z}}$ & & & & & & & $0.9 \mathrm{a}$ & $0.2 \mathrm{a}$ & $2.0 \mathrm{a}$ \\
\hline
\end{tabular}

${ }^{\mathrm{v}}$ Isolation of $B$. cinerea from calyxes of control trees which remained unsprayed throughout the growing season.

${ }^{w}$ Isolation of B. cinerea from calyxes of test trees which received an application of benomyl every 2 weeks, but which remained unsprayed for a 2 -week period.

x Storage in air at $-0.5^{\circ} \mathrm{C}$ for 8 months, followed by a 1 -week ripening period at $20^{\circ} \mathrm{C}$.

y Means down columns followed by the same letter are not significantly different at $P=0.05$ according to Fisher's least significant difference. * Indicates that infection level in nonsprayed control calyxes is significantly different from infection levels in the calyxes sampled after the unsprayed 2-week period from the same orchard according to Fisher's least significant difference $(P=0.05)$.

z \% Calyx end gray mold in nonsprayed control fruit in storage. 
vested fruit by $B$. cinerea conidia present in the air, on fruit surfaces, and in the general fruit environment is an important source of infection resulting in stem end decay in storage (14). Conidia of B. cinerea have been shown to survive for more than 7 months at $-1.1^{\circ} \mathrm{C}(18)$. The application of a contact fungicide shortly before harvest, or a prestorage drench or line spay immediately after harvest would reduce the inoculum levels and protect the abscission zone from infection by $B$. cinerea (13). This recommendation is in agreement with currently recommended management strategies of application of ziram 2 weeks before harvest and a postharvest application of thiabendazole as a drench or line spray $(1,22)$. Controlled atmosphere storage also has been shown to reduce stem end decay $(3,21)$.

It is widely assumed that the major portion of calyx end gray mold in storage is a result of preharvest infection of calyxes in the orchard, and that calyx infections occur at or close to full bloom. Latent infections by fungi (23), and in particular B. cinerea (7), and their implications for postharvest disease control (8) have been reviewed. Infection of pear blossoms by $B$. cinerea occurred through the calyx parts and resulted in latent infections of the calyx $(5,16)$. These latent infections were responsible for calyx end decay in storage $(5,16)$.

Results from inoculation experiments indicate that calyxes are more susceptible to infection early in the growing season (April to May), soon after full bloom, than later in the season. However, inoculation of calyxes in April or May did not result in higher levels of calyx end gray mold in storage. On the contrary, calyxes inoculated during fruit development (June, July, and August) showed higher incidences of calyx end gray mold in storage. Surface disinfestation of calyx parts 1 month after inoculation should have removed surviving, nongerminated $B$. cinerea conidia; thus the $B$. cinerea recovered should have been from infected calyx parts. $B$. cinerea inoculum within calyxes of stored fruit, on the other hand, would be in the form of mycelium in the infected calyx parts $(5,16)$, as well as surviving conidia (17). From these results, it appears that conidia of $B$. cinerea deposited in the calyxes later in the season contribute more to calyx end decay than previously thought.

Early reports indicated that Botrytis species, and in particular B. cinerea, were highly sensitive to benomyl $(2,6,15)$. Spotts and Cervantes (19) found low levels of benomyl resistance in $B$. cinerea isolates collected from the same area of the Pacific Northwest where our benomyl experiment was conducted, and we assumed that the population was sensitive to benomyl.

Chiba and Veres (4) found that benomyl applied to apple foliage in an orchard dis- sipated rapidly during the first week after application but slowed down substantially thereafter. The half-life of benomyl on exposed foliage ranged between 3 and 7 days, depending on rain events. Approximately 2 weeks after spraying, the concentrations of benomyl had fallen to between 14.2 and $32.7 \mathrm{ppm}$. At 18 and 25 days after application, benomyl residue levels were 9.5 and $3.7 \mathrm{ppm}$, respectively. The $\mathrm{EC}_{50}$ of a sensitive $B$. cinerea population ranges from 1 to $5 \mathrm{ppm}$ (2). Based on these results and the benomyl sensitivity of the $B$. cinerea population (19), we assumed that the pear flowers and fruit would be unprotected if left unsprayed for a 2-week period. In reality, the pear material was sampled 28 days after the last benomyl application. For the first 2 weeks, it was protected by the benomyl, then residue levels declined further during the next 14 days and were no longer effective for control of infection.

An effect of skipping benomyl sprays early in the season on calyx infection frequencies, as also detected in the inoculation experiment, was shown only for the 1996 growing season. Calyxes from unprotected control fruit, and from one orchard in 1997, showed greater susceptibility to $B$. cinerea infection in June. These differences could possibly be due to later flowering time in 1997, or differences in favorability of environmental conditions to infection by $B$. cinerea.

Based on results from both inoculation and spray schedule experiments, there was no relationship between the preharvest level of $B$. cinerea infection in calyxes and incidence of calyx end gray mold in storage. These results are contrary to the indirect evidence provided by Sommer et al. (16) that Botrytis blossom end rot (called calyx end gray mold in our study) in stored pear fruit is due in large measure to infection of styles and stamens in the orchard. A possible explanation for these contradictory results is that levels of calyx end gray mold in storage were affected by experimental treatments in Sommer's study (16), whereas this was not the case in our study. Another possible explanation is that the pear cultivar d'Anjou responds differently than the cultivar Bartlett used by Sommer et al. (16). Our results preclude the use of preharvest levels of calyx infection as a predictor of calyx end gray mold in storage in the Mid-Columbia region.

In the spray schedule experiment, benomyl was used to protect calyxes from infection by $B$. cinerea. Although application of this fungicide significantly reduced the level of $B$. cinerea detected in blossoms in some protected trees, application had no effect on subsequent levels of calyx end decay in storage. We conclude from these results that preharvest application of benomyl does not provide significant control of calyx end gray mold in storage. These findings support the current recom- mendation restricting the use of benzimidazole fungicides to postharvest application of thiabendazole as a drench or line spray $(11,13,20)$.

Levels of stem end and calyx end decay in stored fruit from the 14 commercial orchards were variable; some orchards had significantly higher levels of either or both decay types than others. Because both decay types became apparent after 6 months in storage, fruit from orchards with histories of high levels of stem end gray mold should be packed and shipped within 3 to 6 months of harvest.

\section{ACKNOWLEDGMENTS}

We thank Ms. M. Booyse, ARC-Biometry Unit, Private Bag X5013 Stellenbosch, South Africa, for statistical analysis of the data and the Winter Pear Control Committee for partial funding of the research. Use of trade names in this article does not imply endorsement by Oregon State University of the products named or criticism of similar products not mentioned. Oregon Agricultural Experiment Station technical paper 11884 .

\section{LITERATURE CITED}

1. Anonymous 1992. Management practices to minimize postharvest decay of apples and pears. Tree Fruit Postharvest J. 3:5-8.

2. Bollen, G. J., and Fuchs, A. 1970. On the specificity of the in vitro and in vivo antifungal activity of benomyl. Neth. J. Plant Pathol. 76:299-312.

3. Chen, P. M., Spotts, R. A., and Mellenthin, W. M. 1981. Stem-end decay and quality of low oxygen stored d'Anjou pears. J. Am. Soc. Hortic. Sci. 106:695-698.

4. Chiba, M., and Veres, D. F. 1981. Fate of benomyl and its degradation compound methyl 2-benzimidazole carbamate on apple foliage. J. Agric. Food Chem. 29:588-590.

5. De Kock, S. L., and Holz, G. 1992. Blossomend rot of pears: Systematic infection of flowers and immature fruit by Botrytis cinerea. $\mathrm{J}$ Phytopathol. 135:317-327.

6. Edgington, L. V., Khew, K. L., and Barron, G. L. 1971. Fungitoxic spectrum of benzimidazole compounds. Phytopathology 61:42-45.

7. Jarvis, W. R. 1977. Botryotina and Botrytis species: Taxonomy, physiology and pathogenicity. Can. Dep. Agric. Monogr. 15.

8. Jarvis, W. R. 1994. Latent infections in the pre- and postharvest environment. HortScience 29:749-751.

9. Kerssies, A. 1990. A selective medium to be used in a spore-trap. Neth. J. Plant Pathol. 96:247-250.

10. Kupferman, E. 1995. Postharvest handling of Anjou pears. Tree Fruit Postharvest J. 6:3-8.

11. Kupferman, E. 1998. Postharvest applied chemicals to pears: A survey of pear packers in Washington, Oregon and California. Tree Fruit Postharvest J. 9:3-24.

12. Lennox, C. L., and Spotts, R. A. 1997. Botrytis gray mold as a postharvest pathogen in 'd'Anjou' pear. Pages 93-95 in: Proc. Annu. Washington Tree Fruit Postharvest Conf. 13th. E. Kupferman, ed. Washington State Horticultural Association, Wenatchee.

13. Lennox, C. L., Spotts, R. A., and Booyse, M. Incidence of postharvest decay of 'd'Anjou' pears and control with a thiabendazole drench. Plant Dis. In press.

14. Lennox, C. L., Spotts, R. A., and Cervantes, L. A. 2003. Populations of Botrytis cinerea and Penicillium spp. on pear fruit, and in orchards and packinghouses, and their relationship to postharvest decay. Plant Dis. 87:639644.

15. Polach, F. J., and Molin, W. T. 1975. Benzimi- 
dazole-resistant mutants derived from a single ascospore culture of Botryotinia fuckeliana. Phytopathology 65:902-904.

16. Sommer, N. F., Buchanan, J. R., Fortlage, R. J., and Bearden, B. E. 1985. Relation of floral infection to Botrytis blossom-end rot of pears in storage. Plant Dis. 69:340-343.

17. Spotts, R. A. 1985. Effect of preharvest pear fruit maturity on decay resistance. Plant Dis. 69:388-390.

18. Spotts, R. A. 1985. Environmental factors affecting conidial survival of five pear decay fungi. Plant Dis. 69:391-392.

19. Spotts, R. A., and Cervantes, L. A. 1986. Populations, pathogenicity, and benomyl resistance of Botrytis spp., Penicillium spp., and Mucor piriformis in packinghouses. Plant Dis. 70:106-108.

20. Sugar, D., Richardson, D. G., Chen, P. M., Spotts, R. A., Roberts, R. G., and ChandGoyal, T. 1998. Advances in improving the postharvest quality of pears. Acta Hortic.
475:513-526.

21. Sugar, D., Roberts, R. G., Hilton, R. J., Righetti, T. L., and Sanchez, E. E. 1994. Integration of cultural methods with yeast treatment for control of postharvest fruit decay in pear. Plant Dis. 78:791-795.

22. Sugar, D., and Spotts, R. A. 1995. Preharvest strategies to reduce postharvest pear decay. Tree Fruit Postharvest J. 6:13-14.

23. Verhoeff, K. 1974. Latent infections by fungi. Annu. Rev. Phytopathol. 12:99-110. 